\title{
PENERAPAN TEKNIK MODELLING UNTUK MENINGKATKAN SIKAP WIRAUSAHA PADA SISWA
}

\section{THE APPLICATION OF MODELLING METHOD FOR IMPROVING STUDENTS' ENTREPRENEURSHIP ATTITUDE}

\author{
Nur Khixmah Yulihastuti \\ Sekolah Menengah Atas Negeri 2 Pati \\ Email : Nuryuli111@gmail.com
}

\begin{abstract}
Even though the willingness of students to be entrepreneurs tend to increase, it does not followed by their entrepreneurship attitude. The attitude is still low so that it needs to be improved by conducting a certain counseling method. This study aims to investigate the application of modeling technique to improve entrepreneurship attitudes of students. The study was conducted at SMA N 2 Pati from April to June 2016 using qualitative and quantitative approaches (mix method). It involved 35 sample students of 165 students as total population. They were selected using purposive sampling method. Data were collected through direct observation and closed questionnaire using a psychological scale. Furthermore, the data were analyzed descriptively. The results showed that the application of modeling technique potentially increase the entrepreneurship attitude of students.
\end{abstract}

Keywords: content mastering services, entrepreneurship attitude, modelling techniques.

\begin{abstract}
ABSTRAK
Penelitian ini dilatarbelakangi tingginya keinginan peserta didik yang menjadi ampuan peneliti sebagai guru bimbingan konseling untuk bekerja atau berwiraswasta. Namun di sisi lain, dari pengamatan awal peneliti diperoleh temuan bahwa peserta didik masih memiliki sikap wirausaha yang rendah. Oleh karena itu, perlu adanya upaya untuk meningkatkan sikap wirausaha peserta didikdengan menggunakan teknik layanan bimbingan dan konseling tertentu. Penelitian ini bertujuan untuk mengetahui penerapan layanan penguasaan konten dengan teknik modelling dalam meningkatkan sikap wirausaha siswa. Penelitian dilaksanakan di SMA N 2 Pati pada bulan April sampai Juni 2016 dengan menggunakan pendekatan kualitatif dan kuantitatif secara bersama-sama (mix method). Teknik pengumpulan data dengan menggunakan pengamatan (observasi) dan kuesioner tertutup. Data diambil menggunakan skala psikologi selanjutnya data dianalisis secara deskriptif. Populasi sejumlah 165 siswa dengan sampel diambil siswa kelas X IPA 6 berjumlah 35 siswa dengan teknik purposive sampling. Hasil penelitian menunjukkan bahwa terdapat peningkatan sikap wirausaha siswa melalui layanan penguasaan konten dengan teknik modelling.
\end{abstract}

Kata kunci: layanan penguasaan konten, sikap wirausaha, teknik modelling

\section{PENDAHULUAN}

Data out put siswa SMA Negeri 2 Pati pada lima tahun terakhir menun-jukkan bahwa persentase lulusan yang melanjutkan studi ke perguruan tinggi cukup tinggi berkisar $80 \%$, hanya $20 \%$ yang memutuskan untuk kerja dan berwiraswasta. Guru pembimbing menghimpun data minat karier siswa pada awal semester 1 tahun ajaran 2015/2016 melalui layanan klasikal dan pemberian DCM (Daftar Cek Masalah). Hasil DCM pada siswa kelas X IPA 6 menunjukkan bahwa sebagian besar siswa $(60 \%)$ berminat untuk kerja atau wiraswasta sementara sisanya $(40 \%)$ berminat melanjutkan studi ke perguruan tinggi. Hasil wawancara guru pembimbing dengan siswa 
pada saat layanan klasikal di kelas diketahui bahwa faktor utama yang melatarbelakangi minat siswa tidak melanjutkan ke perguruan tinggi adalah kondisi ekonomi orang tua yang tidak mampu untuk membiayai anaknya untuk kuliah di perguruan tinggi.

Berdasarkan data tersebut, guru memutuskan untuk memberikan layanan informasi dengan tema wirausaha yang bertujuan agar jiwa wirausaha pada siswa tumbuh dan menjadi bekal sesudah mereka lulus dari SMA. Hasil evaluasi layanan informasi dengan tema wira-usaha di kelas $\mathrm{X}$ IPA 6 menunjukkan masih rendahnya sikap wirausaha yang terbentuk dalam diri siswa. Layanan yang diselenggarakan konselor belum optimal untuk meningkatkan sikap wirausaha siswa kelas X IPA 6. Oleh karena itu, perlu diselenggarakan layanan yang dapat memfasilitasi siswa untuk belajar menjadi wirausaha dan sikap wirausaha mereka lebih mantap terbentuk. Salah satu layanan yang dapat dilakukan berkaitan dengan hal tersebut di atas adalah layanan penguasaan konten teknik modelling.

Identifikasi masalah yang dialami kelas X IPA 6 adalah siswa belum memahami arti pentingnya sikap wirausaha yang membekali siswa untuk menyelesaikan hambatan dalam melanjutkan pendidikan ke perguruan tinggi karena orang tua yang kurang mampu. Tujuan penelitian ini adalah untuk mengetahui peningkatan sikap wirausaha pada siswa melalui layanan penguasaan konten teknik modelling. Manfaat penelitian ini adalah (1) dapat membantu pengembangan ilmu pengetahuan khususnya bimbingan dan konseling, (2) memperkaya kajian mengenai pelak-sanaan layanan bimbingan dan konseling khususnya layanan penguasaan konten. Bagi siswa, dapat mengembangkan sikap wirausaha melalui kegiatan layanan penguasaan konten dengan teknik modelling.
Bagi konselor, sebagai masukan dalam melaksanakan kegiatan layanan penguasaan konten. Sebagai dasar untuk membuat kebijakan yang tepat terhadap pelaksanaan bimbingan dan konseling di sekolah bersangkutan.

\section{TINJAUAN PUSTAKA}

\section{Wirausaha}

Pengertian wirausaha dalam Kamus Besar Bahasa Indonesia (2008) adalah orang yang pandai mengenali produk baru, menentukan cara produksi baru, menyusun operasi untuk pengadaan produk baru, memasarkan produk baru dan mengatur permodalan perusahaan.

Sejarah awal kewirausahaan di Indonesia dimulai ketika awal tahun 1980-an. Dr. Soeparman Soemahamidjojo secara gencar memasyaratkan kewiraswastaan. Secara harfiah, kata wiraswasta terdiri dari suku kata wira-swa-sta. 'Wira' berarti manusia tunggal, pahlawan, pendekar, teladan, berbudi luhur, berjiwa besar, gagah berani serta memiliki keagungan watak. 'Swa' berarti sendiri atau mandiri. 'Sta' berarti berdiri sendiri" (Astamoen, 2005).

\section{Kepribadian Entrepreneur}

Beberapa ahli mengemukakan sikapistik kepribadian entrepreneur dengan konsep yang berbeda-beda. M. Scarborough dan Thomas W. Zimmerer dalam Suryana (2005) mengemukakan delapan sikapistik kepribadian entrepreneur yang meliputi : Desire for responsibility, Preference for moderate risk, Confedance in their ability to success, Desire for immediate feed back, High level of energy, Future orientation, Skill of organizing,Value of achievement over money.

Berdasarkan pendapat di atas, seorang entrepreneur mempunyai rasa tanggung jawab atas usaha yang dilakukannya. Hal ini berarti 
seorang entrepreneur lebih memilih resiko yang moderat artinya ia akan mengambil resiko dengan menimbang segala sesuatunya, ia mempunyai kepercayaan diri terhadap kemampuan yang dimilikinya untuk mencapai kesuksesan, ia memiliki hasrat yang kuat untuk segera mendapat timbal balik, ia juga memiliki energi yang banyak untuk beraktivitas, ia selalu berorientasi pada masa depan, dan lebih termotivasi untuk mampu berprestasi dari pada sekedar untuk mendapatkan laba.

Hisrich \& Peters (2002) menyatakan bahwa sikap penting dari seorang wirausaha itu ada tiga hal yaitu: (1) Internal Locus of Control yaitu mereka yang merasa bertanggung jawab atas kejadian-kejadian tertentu yang menimpa mereka merupakan hasil atau dampak langsung dari tindakannya; (2) Need For Achievement atau kebutuhan berprestasi merupakan motivasi yang akan memicu seseorang untuk terlibat dengan penuh rasa tanggung jawab, membutuhkan usaha dan keterampilan individu, terlibat dalam resiko sedang, dan memberikan masukan yang jelas; (3) Need For Independent, yaitu keinginan untuk tidak ditentukan oleh orang lain, keinginan untuk independen akan memicu seorang untuk percaya diri pada kemampuan dirinya sendiri dan tidak mudah menyerah tidak mudah meminta bantuan orang lain.

\section{Layanan Penguasaan Konten}

Menurut Tohari (2007) tujuan layanan penguasaan konten secara umum yaitu agar siswa menguasai aspek-aspek konten (kemampuan atau kompetensi) tertentu secara terintegrasi, sedangkan secara khusus dijabarkan sesuai fungsi-fungsi bimbingan dan konseling, yaitu: (1) Fungsi pemahaman; (2) Fungsi pencegahan; (3) Fungsi pengentasan; (4) Fungsi pengembangan dan pemeliharaan. Tujuan layanan penguasaan konten adalah untuk mengembangkan potensi diri siswa sekaligus memelihara potensi-potensi yang telah berkembang pada diri siswa.

Prayitno (2004) menegaskan bahwa dalam pendekatan layanan penguasaan konten ini, konselor sebaiknya menggunakan dua nilai proses pembelajaran, yaitu: (1) High-touch, yaitu sentuhan-sentuhan tingkat tinggi yang mengenai aspek-aspek kepribadian dan kemanusiaan peserta layanan (terutama aspekaspek afektif, semangat, sikap, nilai dan moral); (2) High-tech, yaitu penggunaan teknologi untuk menjamin kualitas layanan penguasan konten. Komponen dalam layanan penguasaan konten terdiri atas: (a) Konselor; (b) Individu; (c) Konten.

Prayitno (2004) menyatakan bahwa penyelenggaraan layanan penguasaan konten secara umum sebagaimana format kegiatan layanan bimbingan dan konseling, yaitu: (1) Individual; (2) Kelompok; (3) Klasikal. Tohirin (2007) menyebutkan bahwa tahaptahap pelaksanaan layanan penguasaan konten diantaranya: (1) Perencanaan; (2) Pelaksanaan; (3) Evaluasi. Selanjutnya Tohirin (2007) menyatakan bahwa penilaian hasil kegiatan pelayanan konseling dilakukan melalui: (a) Penilaian segera (LAISEG); (b) Penilaian jangka pendek (LAIJAPEN); (c) Penilaian jangka panjang (LAIJAPANG).

\section{Teknik Modelling}

Modelling merupakan teori yang yang dikembangkan oleh Bandura. Menurut Anni (2004) menyebutkan bahwa modelling adalah meniru perilaku orang lain dan pengalaman yang dialami oleh orang lain, atau meniru keberhasilan atau kegagalan dari orang lain. Selanjutnya Anni (2004) menjelaskan bahwa modelling dapat membantu klien untuk: (1) Mempelajari sikap, perilaku, ataupun respon yang baru; (2) Mengubah sikap, perilaku atau respon yang sebelumnya berperan sebagai 
penghambat, dan; (3) Mengurangi atau menghilangkan sikap, perilaku atau respon yang tidak pantas atau tidak tepat.

Mappiare (2004) menyatakan bahwa modeling merupakan konsep dari Bandura bagi proses mereproduksi tingkah laku yang dipelajari melalui mengobservasi orang lain, aktifitas/simbol selaku contoh. Modelling dapat diartikan sebagai suatu teknik memanfaatkan suatu model atau contoh sebagai alat mempermudah perubahan tingkah laku.

Tahap modelling menurut Bandura dijelaskan oleh Anni (2004) sebagai berikut: (1) perhatian; (2) retensi; (3) reproduksi; (4) motivasional. Sumber model yang dapat digunakan dalam modelling, antara lain: (1) The client as his or her own model, klien sendiri yang menjadi model, bisa dengan role playing; (2) The counselor as a model, konselor sebagai model; (3) Environmental models, lingkungan sosial digunakan sebagai model; (4) Simbolic models, dapat berupa film, videotape, audiotape, gambar, dll. (Stewart, 1978); 5) "Covert modelling, siswa diajak untuk memba-yangkan seseorang melakukan perilaku yang ingin dipelajari (Sciarra, 2004).

\section{Layanan Penguasaan Konten dengan Teknik Modelling}

Layanan penguasaan konten dengan teknik modelling adalah layanan dalam bimbingan dan konseling dimana siswa yang mendapat layanan ini diharapkan dapat menguasai konten tertentu. Siswa diharapkan dapat menguasai sikap, pola pikir, ataupun perilaku yang dapat mengembangan diri mereka. Kegiatan observasi terhadap suatu model tertentu bertujuan agar siswa dapat mencontoh dan mengaplikasikan pola pikir, sikap serta perilaku model tersebut.

Upaya peningkatan sikap wirausaha ini merupakan pembelajaran untuk mengubah pola pikir dan melatih siswa agar mampu bersikap dan bertindak seperti seorang wirausaha, sehingga guru pembimbing dapat menggunakan layanan penguasaan konten teknik modelling. Berdasar landasan teori dan kerangka berfikir di atas, maka hipotesis penelitian ini adalah layanan penguasaan konten teknik modelling dapat meningkatkan sikap wirausaha siswa kelas X IPA 6.

\section{METODE PENELITIAN}

Penelitian ini merupakan penelitian tindakan bimbingan konseling (PTBK) dengan menggunakan teknik modelling. Alasan dipilihnya teknik modelling dengan menggunakan layanan penguasaan konten adalah untuk memberikan gambaran pengetahuan dan praktik hasil nyata bagi siswa yang berminat untuk meningkatkan diri dan mengembangkan diri di bidang wirausaha dalam meniti masa depannya setelah lulus SMA.

Penelitian ini terdiri dari dua siklus. Setiap siklus terdiri atas 4 (empat) tahap dasar yang saling terkait dan berkesinambungan yang meliputi: perencanan tidakan (planning), pelaksanaan tindakan (action), pengamatan tindakan (observation), refleksi terhadap tindakan (reflection). Penelitian menggunakan pendekatan kualitatif dan kuantitatif secara bersama-sama (mix method). Penelitian dilaksanakan di SMA Negeri 2 Pati selama 3 bulan, dari Bulan April 2016 sampai dengan Bulan Juni 2016.

Populasi dari penelitian ini adalah siswa ampuan peneliti sebagai guru BK sejumlah 165 siswa, meliputi kelas X IPA 6 sebanyak 35 siswa, kelas X IPA 7 sebanyak 40 siswa, kelas X IPS 1 sebanyak 33 siswa, X IPS 2 sebanyak 29 siswa dan kelas X IPS 3 sebanyak 28 siswa. Teknik pengambilan sampel menggunakan purposif sampling, yaitu sampel diambil kelas X IPA 6 sejumlah 35 siswa. Alasan pemilihan siswa kelas X IPA 6 sebagai 
sampel adalah persentase siswa kelas tersebut yang berminat untuk kerja dan wiraswasta paling tinggi dibandingkan kelas-kelas yang lain. Selain itu, terdapat 2 orang siswa kelas $\mathrm{X}$ IPA 6 yang berusaha mencari uang saku dengan cara menitipkan kue-kue di kantin dan berjualan sarapan di kelas pada pagi hari.

Teknik pengumpulan data dengan menggunakan pengamatan (observasi) dan kuesioner tertutup. Data diambil menggunakan skala psikologi dengan menjawab pernyataan menggunakan pilihan jawaban yaitu: sangat tinggi, tinggi, sedang, rendah, sangat rendah. Skala sikap wirausaha yang dimaksudkan untuk mengetahui informasi tentang tingkat sikap wirausaha pada diri siswa.

Skala sikap entrepreneur ini berbentuk pernyataan yang merupakan stimulus untuk memancing jawaban atau respon siswa dimana dari respon tersebut akan dapat diketahui kondisi indikator sikap entrepreneur. Adapun format respon serta skor yang digunakan dalam skala sikap entrepreneur ini adalah sebagai berikut : Skor 5 untuk jawaban Sangat sesuai (SS), skor 4 untuk jawaban Sesuai (S), skor 3 untuk jawaban Tidak Sesuai (TS), skor 2 untuk jawaban Kurang Sesuai (KS) skor 1 untuk Sangat Tidak Sesuai (STS). Kategorisasi dalam skala psikologi bersifat relatif sehingga dapat ditetapkan secara subjektif besarnya luas interval yang mencakup setiap kategori yang diingankan selama penetapan tersebut berada dalam batas kewajaran dan dapat diterima akal (Azwar, 2005).

Sebelum instrumen digunakan, sebanyak 40 item pernyataan dilakukan uji coba. Uji coba dilakukan pada kelas X IPA 7 sebanyak 25 siswa. Hasil uji coba dianalisis uji validitas dan reliabilitasnya. Hasil skor jawaban siswa dibandingkan dengan tabel kriteria sikap wirausaha, dengan kriteria: sangat tinggi (151180), tinggi (121-130), sedang (91-120), rendah (61-90), sangat rendah (30-60).

\section{HASIL DAN PEMBAHASAN}

\section{Siklus I}

Kegiatan diawali dengan penjelasan mengenai wirausaha yang dilanjutkan dengan covert modelling dimana siswa diajak untuk memba-yangkan sosok enterpreneur yang mereka ketahui. Siswa belajar melalui kegiatan covert modelling untuk memahami sikap enterpreneur dengan merekonstruksi dan mengasosiasikan ide dan pengetahuan mereka tentang sosok enterpreneur yang selanjutnya dikem-bangkan lagi melalui proses diskusi sehingga pada akhir kegiatan mereka dapat menyimpulkan bagaimana sikap seorang enterpreneur. Entrepreneur yang mandiri dan kreatif menciptakan ide-ide baru yang dikembangkan dalam berwirausaha.

Gambaran sikap entrepreneur siswa pada saat siklus I berdasarkan skor skala sikap entrepreneur siswa adalah sebagai berikut: (1) Tidak terdapat siswa yang memiliki sikap entrepreneur dengan kriteria tinggi maupun sangat tinggi. (2) Terdapat 5 orang siswa atau $14,28 \%$ dari keseluruhan sampel yang memiliki sikap entrepreneur dengan kriteria sedang. (3) Terdapat 30 orang siswa atau $85,71 \%$ dari keseluruhan sampel yang memiliki sikap entrepreneur dengan kriteria rendah. (4) Tidak terdapat siswa yang memiliki sikap entrepreneur dengan kriteria sangat rendah.

Hasil yang diperoleh dalam pertemuan pertama ini dapat dirinci sebagai berikut: (1) Siswa belum cukup baik dalam memahami arti entrepreneur; (2) Siswa telah mengetahui beberapa sikap dari seorang enterpreneur; (3) Siswa tertarik untuk mengetahui lebih lanjut mengenai sikap enterpreneur; (4) Siswa ingin segera belajar langsung dari seorang enterpreneur; (5) Siswa mampu berpendapat dan aktif berdiskusi; (6) Siswa belajar memahami arti dan sikap dari seorang enterpreneur. 


\section{Siklus II}

Peneliti memberikan penjelasan kepada siswa, dilanjutkan dengan kegiatan modelling (simbolic modelling). Penjelasan yang diberikan tentang layanan penguasaan konten dengan materi memulai bisnis baru selama kurang lebih 60 menit. Adapun kegiatan modelling menghadirkan seorang pengusaha muda yang memberikan contoh dan pengalamannya dalam memulai dan menjalankan bisnisnya. Model menjelaskan berbagai pengetahuan dan pengalamannya dalam memulai bisnis. Siswa tidak hanya belajar mengenai cara memulai bisnis, tetapi semua aspek dari sikap enterpreneur dapat terwakili untuk dipelajari dan diterapkn. Siswa menyatakan sangat senang dengan pertemuan ini, karena dapat belajar langsung dari seorang pengusaha. Banyak pertanyaan yang muncul dari siswa dan dapat dijawab langsung oleh model dengan baik.

Skor skala entrepreneur siswa pada siklus II sebagai berikut : (1) Terdapat 3 orang siswa atau $8,57 \%$ dari keseluruhan sampel yang memiliki sikap entrepreneur dengan kriteria sangat tinggi. (2) Terdapat 28 orang siswa atau $80 \%$ dari keseluruhan sampel yang memiliki sikap entrepreneur dengan kriteria tinggi. (3) Terdapat 4 orang siswa atau 11,42\% dari keseluruhan sampel yang memiliki sikap entrepreneur dengan kriteria sedang.
Hasil yang diperoleh dapat dirinci sebagai berikut: (1) Siswa belajar untuk menjadi seseorang yang berani; (2) Siswa belajar untuk mempunyai visi yang jauh ke depan; (3) Siswa mulai dapat belajar untuk berani menyikapi kesuksesan dan kegagalan; (4) Siswa dapat belajar berani untuk mempelajari hal-hal baru; (5) Siswa mulai berani untuk berpendapat dan melontarkan bayak pertanyaan; (6) Siswa mulai berani untuk belajar lebih bertanggung jawab atas semua tindakannya; (7) Siswa sangat terinspirasi dan termotivasi untuk belajar mandiri seperti pengusaha yang dicontohkan; (8) Siswa sangat tertarik pada contoh kreatifitas seorang pengusaha dan termotivasi untuk melakukan hal yang serupa seperti pengusaha tersebut; (9) Siswa mampu belajar menyikapi kesuksesan dan kegagalan seperti halnya model (pengusaha); (10) Siswa sangat antusias belajar dari pengalaman model, serta sangat berminat untuk menjadi enterpreneur; (11) Siswa makin memerlukan umpan balik yang segera dari model; (12) Siswa dapat memahami arti tanggung jawab dan belajar bertanggung jawab seperti halnya model; (13) Siswa makin siap dan percaya diri ketika nanti akan menghadapi resiko; (14) Siswa dapat belajar menjadi pribadi yang mandiri seperti halnya model; (15) Siswa dapat berlatih menciptakan ide-ide kreatif dan inovatif seperti halnya model.

Tabel 1.

Hasil Skala Sikap Entrepreneur Siklus I dan II

\begin{tabular}{lcccc}
\hline Kriteria & Pre Test & \multicolumn{3}{c}{ Post Test } \\
\cline { 2 - 5 } & Jumlah siswa & $\%$ & Jumlah siswa & $\%$ \\
\hline Sangat Tinggi & 0 & $0 \%$ & 3 & $8,57 \%$ \\
Tinggi & 0 & $0 \%$ & 28 & $80 \%$ \\
Sedang & 5 & $14,28 \%$ & 4 & $11,42 \%$ \\
Rendah & 30 & $85,71 \%$ & 0 & $0 \%$ \\
Sangat Rendah & 0 & $0 \%$ & 0 & $0 \%$ \\
\hline
\end{tabular}


Sebelum mendapatkan layanan penguasaan konten dengan teknik modelling, sikap enterpreneur siswa telah terbentuk. Namun minat siswa untuk mempelajari kewirausahaan masih kurang. Kondisi ini menyebabkan sikap enterpreneur dalam diri siswa belum berkembang optimal.

Setelah mendapat layanan penguasaan konten dengan teknik modelling, sikap enterpreneur siswa dapat dikembangkan dari kriteria sedang menjadi tinggi. Hal ini terjadi karena dalam kegiatan layanan penguasaan konten dengan teknik modelling, siswa secara sungguh-sungguh menyimak dan mempelajari pengalaman model seorang pengusaha muda, sehingga mereka dapat mencontoh pemikiran, sikap dan perilaku enterpreneur tersebut.

Siklus I tidak terdapat seorang pun siswa yang memiliki sikap entrepreneur dengan kriteria sangat tinggi, tetapi setelah siklus II terdapat 3 orang siswa atau $8.57 \%$ dari keseluruhan sampel memiliki sikap entrepreneur dengan kriteria sangat tinggi. (2) Pada siklus I tidak terdapat seorang pun siswa yang memiliki sikap entrepreneur dengan kriteria tinggi, tetapi setelah siklus II terdapat 28 orang siswa atau $80 \%$ dari keseluruhan sampel memiliki sikap entrepreneur dengan kriteria tinggi. (3) Pada siklus I terdapat 5 orang siswa atau $14,28 \%$ dari keseluruhan sampel memiliki sikap entrepreneur dengan kriteria sedang, tetapi setelah siklus II terdapat 4 orang siswa atau $11,42 \%$ dari keseluruhan sampel memiliki sikap entrepreneur dengan kriteria sedang. (4) Pada silkus I terdapat 30 orang siswa atau $85,71 \%$ dari keseluruhan sampel memiliki sikap entrepreneur dengan kriteria rendah. (5) Pada silkus I tidak terdapat siswa dari keseluruhan sampel memiliki sikap entrepreneur dengan kriteria sangat rendah.

Terdapat perbedaan tingkat sikap enterpreneur dalam diri siswa antara sebelum dan sesudah pelaksanaan layanan penguasaan konten dengan teknik modelling. Sikap enterpreneur siswa mengalami peningkatan setelah pelaksanaan layanan penguasaan konten dengan teknik modelling dari kriteria sedang menjadi kriteria tinggi.

\section{KESIMPULAN DAN SARAN}

\section{Kesimpulan}

Terdapat perbedaan tingkat sikap entrepreneur dalam diri siswa antara pada siklus I dan II. Sebelum dilakukan tindakan (Siklus I), sikap entrepreneur yang dimiliki peserta didik termasuk dalam kriteria sedang. Setelah dilakukan tindakan (Siklus II) sikap entrepreneur siswa meningkat dan masuk dalam kriteria tinggi.

\section{Saran}

Guru pembimbing apabila hendak mengembangkan jiwa wirausaha pada diri siswa melalui layanan penguasaan konten dengan teknik modelling sebaiknya memperhatikan pemilihan model yang mempunyai pengalaman berwirausaha dari nol, menemui banyak kegagalan, hingga akhirnya dapat meraih kesuksesan.

Kepala sekolah perlu meningkatkan kerjasama dengan para enterpreneur, baik enterpreneur lokal maupun nasional. Enterpreneur dapat diundang sebagai narasumber dan model atau contoh bagi siswa.

\section{DAFTAR PUSTAKA}

Anni, C. T. (2004). Psikologi Belajar. Semarang: UNNES Pers.

Astamoen. (2005). Ensiklopedia Wirausaha. Jakarta : Grasindo.

Azwar, S. (2005). Penyusunan Skala Psikologi. Yogyakarta : Pustaka Pelajar.

Hisrich, R. D., Peters, M. P. (2002). Enterpreneurship. New York :McGrawHill/Irwin 
Mappiare A. T. A. (2006). Kamus Istilah Konseling \& Psikoterapi. Jakarta : PT Raja Grasindo Persada.

Prayitno. (2004). Dasar-dasar Bimbingan dan Konseling. Jakarta: PT. Asdi Mahasatya

Pusat Bahasa Depdiknas. (2008). Kamus Besar

Bahasa Indonesia. Jakarta : Gramedia Pustaka.

Sciarra, D. T. (2004). School Counseling Foundations and Contemporary Issues. Canada : Brooks/Cole, a division of Thomson Learning Inc.109

Stewart, N. R. (1978). Systematic Counseling. USA : Prentice-Hall, Inc
Suryana. (2005). Kewirausahaan (Pedoman Praktis, Kiat dan Proses Menuju Sukses). Jakarta: Salemba Empat.

Tohari. (2007). Bimbingan dan Konseling di Sekolah dan Madrasah (Berbasis Integrasi). Jakarta: PT. Raja Grafindo Persada.

\section{BIODATA PENULIS:}

Nur Khixmah Yulihastuti, lahir 19 Juli 1975 di Kabupaten Pati. Menyelesaikan studi S1 pada jurusan Bimbingan Konseling di Universitas PGRI Semarang dan Gelar Magister Pendidikan (M.Pd) diperoleh dari program studi Pendidikan Ekonomi Universitas Sebelas Maret Surakarta. Saat ini bekerja sebagai guru di SMAN 2 Pati. 